\title{
Seasonal cycles of biogenic volatile organic compound fluxes and concentrations in a California citrus orchard
}

\author{
S. Fares ${ }^{1,2}$, J.-H. Park ${ }^{1}$, D. R. Gentner ${ }^{3}$, R. Weber ${ }^{1}$, E. Ormeño ${ }^{1,4}$, J. Karlik ${ }^{5}$, and A. H. Goldstein ${ }^{1,3}$ \\ ${ }^{1}$ Division of Ecosystem Sciences, Department of Environmental Science, Policy, and Management, University of California, \\ Berkeley, CA, USA \\ ${ }^{2}$ Consiglio per la ricerca e la sperimentazione in agricoltura, Research Center for the Soil-Plant System, Rome, Italy \\ ${ }^{3}$ Department of Civil and Environmental Engineering, University of California, Berkeley, CA, USA \\ ${ }^{4}$ Aix-Marseille Université - Institut méditerranéen de biodiversité et écologie IMBE CNRS UMR7263, France \\ ${ }^{5}$ Cooperative Extension Kern County, University of California, 1031 South Mount Vernon Avenue, Bakersfield, \\ CA 93307, USA
}

Correspondence to: S. Fares (silvano.fares@entecra.it)

Received: 22 May 2012 - Published in Atmos. Chem. Phys. Discuss.: 19 July 2012

Revised: 1 October 2012 - Accepted: 8 October 2012 - Published: 29 October 2012

\begin{abstract}
Orange trees are widely cultivated in Mediterranean climatic regions where they are an important agricultural crop. Citrus have been characterized as emitters of volatile organic compounds (VOC) in chamber studies under controlled environmental conditions, but an extensive characterization at field scale has never been performed using modern measurement methods, and is particularly needed considering the complex interactions between the orchards and the polluted atmosphere in which Citrus is often cultivated. For one year, in a Valencia orange orchard in Exeter, California, we measured fluxes using PTRMS (Proton Transfer Reaction Mass Spectrometer) and eddy covariance for the most abundant VOC typically emitted from citrus vegetation: methanol, acetone, and isoprenoids. Concentration gradients of additional oxygenated and aromatic compounds from the ground level to above the canopy were also measured. In order to characterize concentrations of speciated biogenic VOC (BVOC) in leaves, we analyzed leaf content by GC-MS (Gas Chromatography - Mass Spectrometery) regularly throughout the year. We also characterized in more detail concentrations of speciated BVOC in the air above the orchard by in-situ GC-MS during a few weeks in spring flowering and summer periods. Here we report concentrations and fluxes of the main VOC species emitted by the orchard, discuss how fluxes measured in the field relate to previous studies made with plant enclosures, and describe how VOC content in leaves and emissions change during the year in response
\end{abstract}

to phenological and environmental parameters. The orchard was a source of monoterpenes and oxygenated VOC. The highest emissions were observed during the springtime flowering period, with mid-day fluxes above $2 \mathrm{nmol} \mathrm{m}^{-2} \mathrm{~s}^{-1}$ for methanol and up to $1 \mathrm{nmol} \mathrm{m}{ }^{-2} \mathrm{~s}^{-1}$ for acetone and monoterpenes. During hot summer days emissions were not as high as we expected considering the known dependence of biogenic emissions on temperature. We provide evidence that thickening of leaf cuticle wax content limited gaseous emissions during the summer.

\section{Introduction}

Oranges, Citrus sinensis L., are among the most economically important and widely cultivated crops in areas with Mediterranean climates, such as California, Italy, Spain, Morocco, and Israel, and areas of cultivation are often close to densely populated areas. All vascular plants including Citrus species emit biogenic volatile organic compounds (BVOC), with a global estimate of BVOC emitted from plants in the range of 1-1.5 $\mathrm{Pg} \mathrm{C} \mathrm{yr}^{-1}$ (Guenther et al., 1995). In the presence of sunlight and nitrogen oxides $\left(\mathrm{NO}_{\mathrm{x}}\right)$, the oxidation of BVOC can lead to formation of tropospheric ozone (Chameides et al., 1988; Papiez et al., 2009), a greenhouse gas with detrimental effects on plant health, crop yields, and human health (for a reference list, see EPA 2011). BVOC are also 
precursors to atmospheric aerosol formation (Henze and Seinfeld, 2006), accounting for a significant fraction of secondary organic aerosol (SOA) produced in the atmosphere (Goldstein and Galbally, 2007).

The Mediterranean climates where citrus is cultivated are characterized by high summer temperatures. Emission of BVOC from Citrus is known to be temperature dependent due to volatilization from organs (ducts, glands) where BVOC are stored (Kesselmeier and Staudt, 1999), as shown in recent studies using branch enclosure techniques (Fares et al., 2011). In these studies, performed under controlled conditions and in the absence of any environmental stress, monoterpenes were the most abundant isoprenoids emitted by oranges. Sesquiterpenes were another important class of isoprenoids whose emissions depended primarily on temperature, but they are formed by different biosynthetic pathways than monoterpenes (for a review see Duhl et al., 2008). In addition to these reactive isoprenoids, oranges were shown to emit oxygenated volatile organic compounds (OVOC), which from biogenic sources are products of catabolism and depend mostly on temperature, but also on light conditions. Among OVOC, methanol is a plant volatile emitted to the atmosphere in large quantities from the demethylation of pectins in cell walls with global emissions estimated at 100$240 \mathrm{Tg} \mathrm{yr}^{-1}$ (Galbally and Kirstine, 2002; Jacob et al., 2005; Millet et al., 2008). Acetone and acetaldehyde are also important primary OVOC emitted from terrestrial ecosystems and oceans, but these are also produced in the atmosphere in large quantity as secondary compounds from oxidation of hydrocarbons of both anthropogenic and biogenic origin (Goldstein and Schade, 2000). The contribution of cultivated Citrus to VOC emissions in polluted or highly populated regions is poorly understood, but may be signficant considering that these compounds could notably influence the ozoneforming potential of the atmosphere, affect concentrations of HOx and peroxyacetyl nitrates, and contribute to the formation of organic aerosol (Singh et al., 2001; Steiner and Goldstein, 2007).

The Central Valley of California is a region with both extensive agriculture and anthropogenic pollution. Its southern half, the San Joaquin Valley, experiences pollution from large nearby cities (e.g. Fresno, Bakersfield, Modesto, Stockton), as well as inflow of pollution from populated coastal regions (e.g. the San Francisco Bay area). We chose an experimental site in the southern half of the San Joaquin Valley where citrus, especially oranges and mandarins, are extensively cultivated. Here we report results of a one-year study at that site, specifically: (1) to quantify concentrations and fluxes of the main BVOC species "in-situ" using proton transfer reaction mass spectrometry (PTRMS) and the eddy covariance technique, along with in-situ gas chromatography; (2) to determine how fluxes measured in the field relate to previous studies made with plant enclosures; (3) to investigate how BVOC content in leaves and emissions change during the year in response to phenological and environmental parameters.

\section{Material and methods}

\subsection{Site description}

The measurement site was located in a private Valencia Orange orchard three $\mathrm{km}$ west of the University of California Lindcove Research and Extension Center near Visalia, California, USA. For a more detailed description of the site location, soil and plant characteristics, spacing of the plantation, irrigation treatments please refer to Fares et al. (2012). The site is characterized by a Mediterranean climate, with warm dry summers and cold wet winters, and a typical wind pattern which brings daytime air up the mountain slopes of the Sierra Nevada Mountains from the nearby urban area of Visalia, while at night a gentle downslope wind reverses the direction. For the measurement period, precipitation, daily and hourly averaged data of air temperature, photosynthetic active radiation (PAR) and turbulence $\left(u^{*}\right)$ are shown in detail in Fares et al. (2012).

Measurements started in October 2009, and ended in November 2010. A shipping container was fitted with air conditioning and electrical wiring to serve as a field lab, and set in the orchard in September, 2009, to house analytical instruments in a temperature controlled environment. Sensors and inlet lines were attached to a telescoping tower, (Floatograph FM50 telescoping mast), $9.8 \mathrm{~m}$ tall, and located $5 \mathrm{~m}$ away from the field lab, on the same tree-line. The tower was equipped with meteorological sensors replicated at four measuring heights $(9.18,4.85,3.76,1 \mathrm{~m})$. The height-replicated measurements included air temperature, relative humidity $(\mathrm{RH})$, and wind speed. Other measured environmental variables included photosynthetically active radiation (PAR) (LiCor Inc., Lincoln, NE) and soil moisture (Campbell Scientific Inc., Logan, UT). A system of fine wire thermocouples was used to measure leaf temperatures (Omega Engineering, Precision Fine Wire thermocouples). All data were recorded at $1 \mathrm{~min}$ intervals using dataloggers (CR10x and CR3000, Campbell Scientific Inc., Logan, UT).

To be able to relate flux measurements to Citrus leaf mass and leaf area, we harvested a 'Valencia' orange tree from within the study block in August 2010. We measured five composite samples of fresh leaves with a Licor leaf area meter (mod. LI-3100 C), then dried the samples. All leaves were removed from the citrus tree, dried, and weighed. Leaf area for the whole tree was calculated using the mass-to-area conversion obtained from the leaf samples as applied to total leaf mass for the tree. We measured the number of trees per ha using Google Earth imagery and ground measurements. The leaf area index (LAI) for the orchard was $3.00 \mathrm{~m}_{\text {leaves }}^{2} \mathrm{~m}_{\text {soil }}^{-2}$. The average height of the trees surrounding the field lab and tower was $4.2 \pm 0.23 \mathrm{~m}(n=11)$. 


\subsection{PTRMS system for flux and gradient measurement}

VOC mixing ratios were measured in situ by ProtonTransfer-Reaction Mass Spectrometer (PTR-MS), which has been described elsewhere in detail (Lindinger et al., 1998). During each hour air was sampled through five individual gas inlets made of Teflon with $4 \mathrm{~mm}$ internal diameter, each of which was protected by a Teflon filter (PFA holder, PTFE membrane, pore size $2 \mu \mathrm{m}) 30 \mathrm{~cm}$ from the inlet. The filters were replaced every 2 weeks, a time interval considered adequate to avoid contamination or flow problems based on past research (Holzinger et al., 2005). One inlet was used to sample air at $4.85 \mathrm{~m}$ from 0 to $30 \mathrm{~min}$ for eddy-covariance flux measurements of methanol, acetone, isoprene, monoterpenes and an oxidation product, with $\mathrm{m} / z$ of $33,59,69,81$, 113 , respectively. The measurement cycle duration for these 5 masses including water was $1.1 \mathrm{~s}$. The sampling tube was $15 \mathrm{~m}$ long and heated at a constant temperature of $40^{\circ} \mathrm{C}$ to avoid condensation inside the tubing. A sample flow of $10 \mathrm{~L} \mathrm{~min}^{-1}$ was generated with a diaphragm pump and maintained by a mass flow controller (MKS Instruments). Four additional inlets were used to sample vertical gradients at height-levels within $(1 \mathrm{~m}, 3.76 \mathrm{~m})$ and above $(4.85 \mathrm{~m}$ and $9.18 \mathrm{~m}$ ) the canopy sequentially for $6 \mathrm{~min}$ each during the second $30 \mathrm{~min}$ of each hour. In order to avoid different retention times of the air in the inlet lines, we used tubing with the same length for each inlet line $(20 \mathrm{~m})$. Table 1 lists the $\mathrm{m} / \mathrm{z}$ monitored, the corresponding compounds, and the dwell time for each mass. Each sampling line was connected to a 3-way solenoid valve (TEQCOM Industries) controlled by a datalogger (mod. CR10x, Campbell Sci.). Air was continuously pulled through each sampling line to avoid memory effects of the air retained in the lines.

The instrument sampled from the main sampling line at $0.4 \mathrm{~L} \mathrm{~min}^{-1}$ and was optimised to an $\mathrm{E} / \mathrm{N}$ ratio of $128 \mathrm{Td}$ using a drift tube pressure, temperature, and voltage of $2.02 \mathrm{hPa}, 45^{\circ} \mathrm{C}$, and $600 \mathrm{~V}$, respectively. The reaction time was $100 \mu$ s and the count rate of $\mathrm{H}_{3} \mathrm{O}^{+} \mathrm{H}_{2} \mathrm{O}$ ions was less than $3 \%$ of the count rate of $\mathrm{H}_{3} \mathrm{O}^{+}$ions, which was $\sim 5 \times 10^{6}$ counts s$^{-1}$. Each measurement cycle lasted $\sim 2$ minutes, totalling 13 measured cycles per level for each hour. The first two cycles were discarded to prevent eventual error due to missed synchronization between the PTRMS and the datalogger clocks. The instrumental background signal was measured by directing the sample flow through a catalyst-based purifier for the first 3 minutes before starting the measurements in the second half of each hour, similar to Holzinger et al. (2005). The purifier consisted of a stainless steel tube filled with platinum-coated quartz wool (Shimadzu) heated to $350^{\circ} \mathrm{C}$, which efficiently removed the VOC but not the water vapor from the sample. This is important because the background impurities may depend on the humidity of the sampled air.

Gas samples from gravimetrically-prepared standard cylinders (Apel \& Riemer) of pure nitrogen with known mix- ing ratios (4-5 ppm) of methanol, acetaldehyde, acetone, isoprene, methyl-vinyl-ketone, benzene, hexenal, d-limonene, $\Delta$-3-carene were automatically measured twice a day (at hours $02: 00$ and 16:00) by dynamically diluting with purified air to obtain concentrations in the range of $10-50 \mathrm{ppb}$, which were similar to those expected in the atmosphere. The count signal was then transformed to ppb after subtracting the averaged background levels and taking into account the measured sensitivities for each calibrated compound (i.e. counts/ppb, Davison et al., 2009). For concentrations of the other masses for which authentic standards were not available, we calculated normalized sensitivities (counts/ppb) based on theoretical proton transfer reaction rate coefficients and the instrument-specific transmission coefficient calculated from a transmission curve, as described by Holzinger et al. (2005). This curve was determined at an array of masses from 33 to $219 \mathrm{~m} / \mathrm{z}$ using our gas standards at concentrations of $100 \mathrm{ppb}$ (Apel \& Riemer). However, the interpretation of concentration of masses with molecular weight higher than 140 can be overestimated, since after this limit the transmission efficiency is decreased due to insufficiently tuned mass scale of the mass spectrometer and aging of the secondary electron multiplier (SEM).

\subsection{GC/MS instrument for chemically-speciated BVOC measurements}

Hourly-resolved VOC concentrations were measured using an automated in-situ gas chromatograph (Agilent mod. 5890) equipped with a mass-selective detector (Agilent mod. 5971). The instrument was operated in-situ with a custom system that automated sample collection and analysis. Ambient samples were collected for the first 30 minutes of every hour via an inlet located at a height of $4 \mathrm{~m}$. Ozone and particulate matter were removed at the inlet using $47 \mathrm{~mm}$ glass fiber filters (Pall, type $\mathrm{A} / \mathrm{E}$ ) that were coated in sodium thiosulfate according to the method vetted by Pollmann et al. (2005). After ozone and particulate removal, the sample travelled down a $1 / 4^{\prime \prime}$ heated Silcosteel line at $\sim 1 \mathrm{~L} \mathrm{~min}^{-1}$ to a preconcentration system, where a $\sim 600 \mathrm{~mL}$ sample was concentrated on a custom-made adsorbent trap (glass beads: Tenax TA: Carbopak B: Carbopak X held in place by glass wool on each end) and thermally desorbed onto a DB-624 capillary column $(60 \mathrm{~m} \times 0.32 \mathrm{~mm} \times 1.8 \mu \mathrm{m})$, and then analyzed by the MSD. Daily calibration checks and blank runs were performed using gas-phase standards and a zero air generator. Calibrations were performed using gas-phase monoterpene standards and liquid standards for more reactive compounds (e.g. sesquiterpenes and unstable monoterpenes).

\subsection{BVOC Flux calculation}

Wind velocity and sonic virtual temperature fluctuations were measured at $10 \mathrm{~Hz}$ with a three-dimensional sonic anemometer (Applied Technologies, Inc., Boulder, CO) 

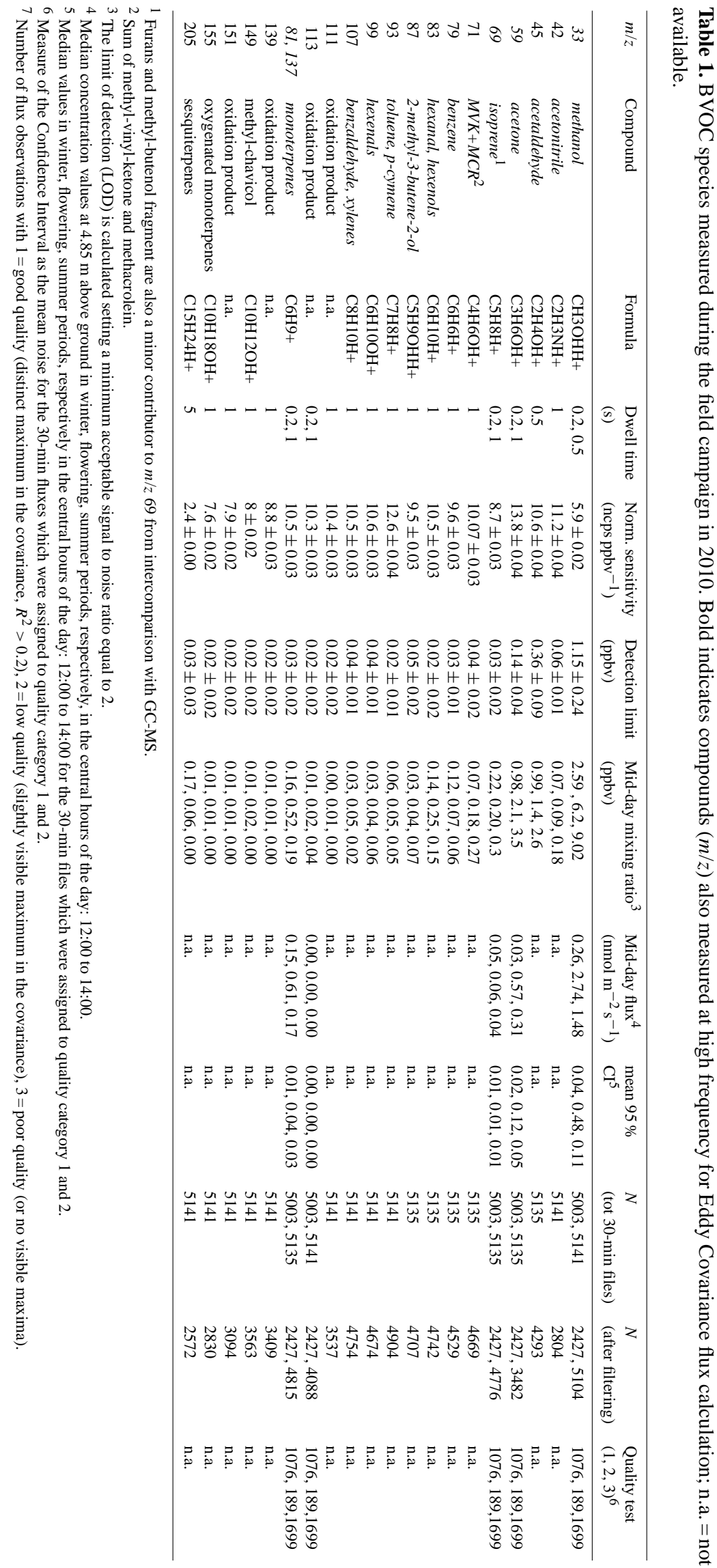
Table 2. BVOC basal emission factors (BEF, nmol m $\mathrm{m}^{-2} \mathrm{~s}^{-1}$ ) of valencia Orange for winter, flowering, summer periods, respectively. The $\beta$ value calculated from the Tingey $(\mathrm{T})$ algorithm is reported below for each BVOC species. Data \pm standard deviations refer to basal conditions of Temperature $=30 \pm 2{ }^{\circ} \mathrm{C}$ extrapolated from the observations. BEF for the 2010 field experiment were calculated using $\beta$ values from the greenhouse experiment using plant cuvettes because in the greenhouses the environmental conditions were close to basal condition thus providing a more robust dataset for $\beta$ calculation. $\beta$ from summer 2008 was used to calculate BEF for winter period. Leaf-scale BEF measured using enclosures were up-scaled to canopy level by multiplying by Leaf Area Index (LAI $=3 \mathrm{~m}^{2}$ (leaf) $\mathrm{m}^{-2}$ (ground)).

\begin{tabular}{lll}
\hline & 2008 Cuvette & 2010 Field (using beta from 2008) \\
\hline $\begin{array}{l}\text { Monoterpenes } \\
\beta\end{array}$ & n.a., $6.29 \pm 1.73,2.01 \pm 1.37$ & $0.87 \pm 0.49,1.31 \pm 1.51,0.13 \pm 0.13$ \\
Methanol & n.a., $0.15 \pm 0.016,0.14 \pm 0.014$ & \\
$\beta$ & n.a., $7.11 \pm 1.11,3.87 \pm 1.61$ & $0.66 \pm 1.2,3.98 \pm 3.21,0.22 \pm 0.23$ \\
$\begin{array}{l}\text { Acetone } \\
\beta\end{array}$ & n.a., $0.59 \pm 0.04,0.59 \pm 0.011$ & \\
\hline
\end{tabular}

mounted on a horizontal beam with the air sample inlet attached inside the anemometer structure. The wind data were rotated according to the planar fit method (Wilczak et al., 2001). The lag interval between the instantaneous vertical wind velocity and the BVOC concentration measurement varied due to changes in clock synchronization between the PTRMS clock and the datalogger where sonic data were stored. To calculate this lag time, for each specific 30-min measurement period, vertical wind velocity and concentration were correlated in $\mathrm{a} \pm 10 \mathrm{~s}$ time window and indentifying the lag time in correspondence of the maximum covariance, similarly to Ruuskanen et al. (2011). In cases in which a clear covariance peak was not observed, we used the lag time measured closest in absolute temporal scale.

Fluxes of BVOC $\left(F_{c}\right.$, nmol m${ }^{-2} \mathrm{~s}^{-1}$, Eq. 1) were calculated using the continuous flow disjunct Eddy Covariance method (Karl et al., 2002) in which fluxes are calculated from a subsample of the vertical wind data corresponding to data collected with the PTRMS after subtracting the lag time $(\Delta \mathrm{t})$ :

$F_{c}=\frac{\sigma}{N} \sum_{i=1}^{N} w^{\prime}\left(i-\Delta t / \Delta t_{w}\right) c^{\prime}(i)$

where $\sigma$ is the air density (mol m-3), $w^{\prime}=w-\bar{w}$ is the instantaneous deviation of the vertical wind speed $(w)$ from its average, $c^{\prime}=c-\bar{c}$ is that of the BVOC concentration $\left(\mathrm{nmol} \mathrm{mol}^{-1}\right), \Delta \mathrm{tw}$ is the sampling interval in the wind measurements $(0.1 \mathrm{~s})$, and $N$ is the number of PTR-MS measurement cycles (1680) during the flux averaging time (29.5 min).

A de-spiking routine was applied to exclude points clearly resulting from interferences. We considered outlier points where the difference from the averaged signal during the half hour was 10 times higher than the theoretical standard deviation (Bamberger et al., 2010). The response time of the instrument is $0.1 \mathrm{~s}$ (Lindinger et al., 1998). Measured fluxes were multiplied by a frequency response corrections factor compensating for the high frequency attenuation caused by the response time of the PTR-MS calculated using the for- mula and parameterization suggested by Horst (1997). We found that mid-day high-frequency attenuation was about 0.90 . Flux values were discarded if at least one of the following conditions were met: (1) measured ambient concentration was close to the detection limit of the specific VOC. (2) Results from the stationary test for the various BVOC were above $60 \%$ (Foken and Wichura, 1966). (3) the footprint area was outside the boundaries of the orchard (Hsieh et al., 2000). (4) turbulence was low $\left(u^{*}<0.15\right)$, a very frequent occurrence at our measuring site during night hours.

The uncertainty was measured according to the method proposed by Wienhold et al. (1994) determining the signal noise of the covariance by calculating the time shifts between vertical wind velocity and BVOC concentration far beyond the true lag-time. We used the same procedure recently adopted by Ruuskanen et al. (2011) using a lag window of $40 \mathrm{~s}$ and rated the 30-min flux data in three classes: (1) good quality, (2) low quality, (3) poor quality, as reported in Table 1. All data processing was computed using a Matlab routine.

\subsection{Analysis of BVOC concentrations in leaves and cuticle waxes}

Storage of both leaf BVOC and waxes, which occurs in secretory cells and cuticles respectively, were extracted by suspending leaf dry matter $(1 \mathrm{~g})$ in hexane in a ratio of $1: 5 \mathrm{w} / \mathrm{v}$ containing $0.0123 \mathrm{mg} \mathrm{mL}^{-1}$ of dodecane (internal standard for quantitation) for $30-40 \mathrm{~min}$ with constant shaking at room temperature, according to the method in Ormeño et al. (2010).

Stored BVOC and waxes were analyzed by GC (Hewlett Packard® GC 6890) coupled to a MSD (5973 Network) with an HP-5MS capillary column $50 \mathrm{~m} \times 0.20 \mathrm{~mm} \times 0.33 \mu \mathrm{m}$. Four $\mu \mathrm{L}$ of extracts were injected through an automatic injector (ALS 7683) at $280^{\circ} \mathrm{C}$ in split mode (5:1) with purge flow of $20 \mathrm{~mL} \mathrm{~min}^{-1}$ after $5 \mathrm{~min}$. Helium carrier gas was used with constant flow rate of $1 \mathrm{~mL} \mathrm{~min}^{-1}$. The oven temperature program was $50^{\circ} \mathrm{C}$ for $2 \mathrm{~min}$, increasing to $200^{\circ} \mathrm{C}$ 


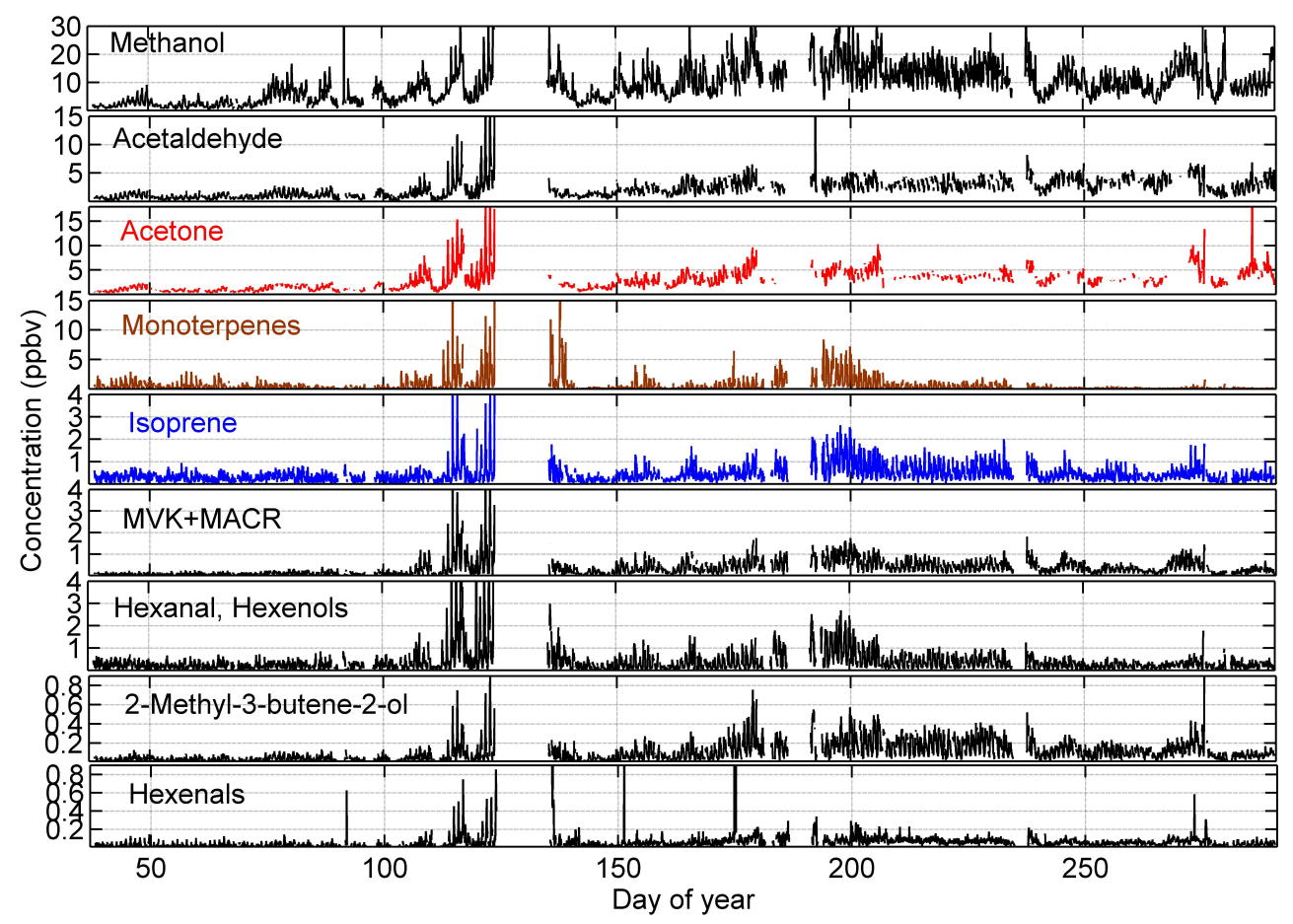

Fig. 1. Concentration of the major BVOC species measured hourly by PTRMS at $4.85 \mathrm{~m}$ above ground at the Citrus site between February and November 2010.

at $4{ }^{\circ} \mathrm{C} \min ^{-1}$, then increasing to $320^{\circ} \mathrm{C}$ at $20^{\circ} \mathrm{C} \mathrm{min}^{-1}$ and then held constant for $15 \mathrm{~min}$. The MSD transfer line heater was maintained at $330^{\circ} \mathrm{C}$. Mass detector parameters were: ion source, $230^{\circ} \mathrm{C}$; quadrupole, $150^{\circ} \mathrm{C}$; EI, $70 \mathrm{eV}$; EMV, $1530 \mathrm{~V}$; acquisition in scan mode from 40 to $800 \mathrm{amu}$.

Terpenes and waxes were identified by comparison of their retention index (RI) and mass spectra with those reported in published mass spectra libraries (Adams, 2007). Quantification was achieved based on relative response factors calculated for each single standard compound, when available.

\section{Results and discussion}

We report here the most extensive in-situ measurements of a suite of BVOC concentrations and fluxes observed to-date in a citrus orchard. For most of the measured compounds reported in Table 1, we show the concentration at $4.85 \mathrm{~m}$ averaged every 30-min for the full measurement year (Fig. 1). Some of the compounds reported in Table 1 have not been discussed in detail since their concentration was close or below the detection limit of the instrument. This is the case of acetonitrile $(\mathrm{m} / \mathrm{z}$ 42), the unknown $\mathrm{m} / \mathrm{z} 111,113,139$ and 151 , here reported only for comparison with previous works where these masses have been observed in relevant amount (Holzinger et al., 2006), and methylchavicol ( $\mathrm{m} / \mathrm{z}$ 149), another compound emitted in large amount from pines and palms, but relevant here (Bouvier-Brawn et al., 2009; Misztal et al., 2010). We also show vertical gradients averaged over the diurnal cycle by interpolation of mean mixing ratios at the measurement heights of $1 \mathrm{~m}, 3.76 \mathrm{~m}, 4.85 \mathrm{~m}$ and $9.18 \mathrm{~m}$ (Figs. 2, 3) during three representative periods in the year: flowering (DOY 130-140), summer (DOY 172-274), winter (DOY 37-80), and the fluxes measured over the full year (Fig. 4). The year-long database allowed us to calculate the basal emission factors (BEF) of the temperature-dependent BVOC for the most important seasons (Table 2) using an exponential temperature dependence (Guenther et al., 1995; Tingey et al., 1991).

For most compounds, it was evident that the ambient concentration followed a diurnal cycle that was dependent on changes in boundary layer dynamics, with additional influences from differences in regional photochemistry (Figs. 2, 3, $8,9)$. The result was higher concentration at night and lower during the day, with the exception of OVOC during winter period, for which we observed higher concentrations during the day as combination of changes in emissions and boundary layer dynamics. These dynamics in the Central Valley have recently been described by Bianco et al. (2011). During the day, when convective heat expands the boundary layer thus increasing the vertical mixing volume, ambient concentrations decrease. Lower mid-day concentrations are typical of plant ecosystems with both day and night emissions because the boundary layer is shallower at night causing the local concentration of emitted BVOC to increase. The boundary layer dynamic also influences ability to measure fluxes. Large gradients during the night were indicative of extremely 


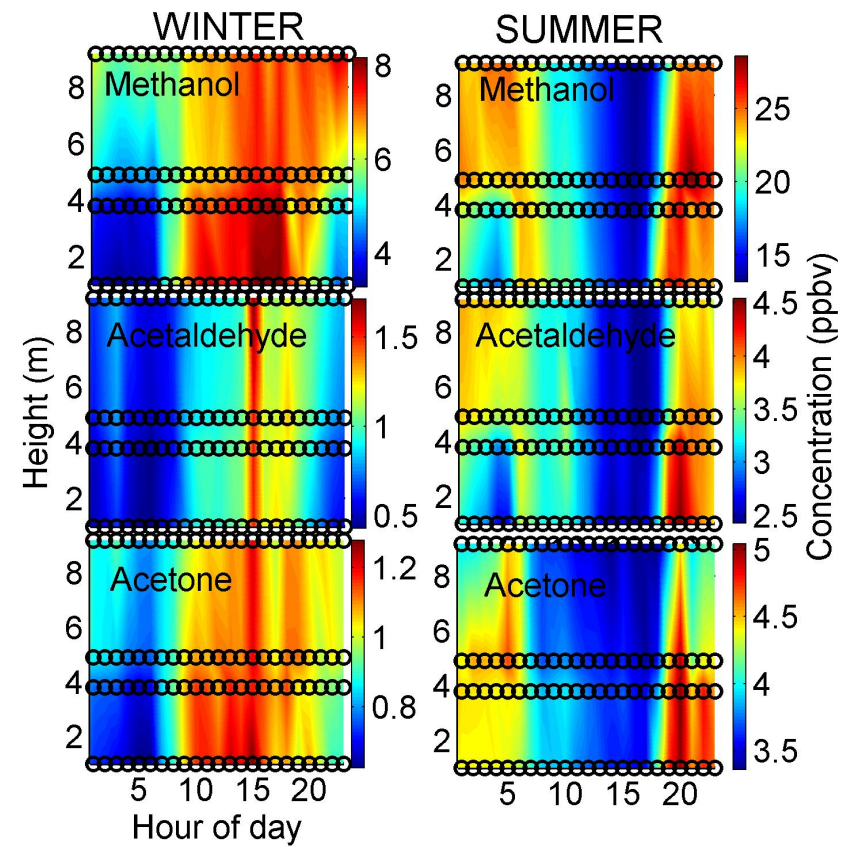

Fig. 2. Hourly average winter (DOY 37-80) and summer (DOY 172-274) vertical profiles of the major OVOC species measured by PTRMS (methanol, acetaldehyde, acetone) within ( $1 \mathrm{~m}, 3.76 \mathrm{~m})$ and above $(4.85 \mathrm{~m}$ and $9.18 \mathrm{~m}$ ) the orange orchard canopy (circles indicate measurement heights).

slow vertical mixing, making vertical fluxes difficult or impossible to measure by eddy covariance. The daily dynamic of measured fluxes showed maximum peaks in the central hours of the day with minima at night (Fig. 5).

\subsection{OVOC concentrations and fluxes}

\subsubsection{Methanol}

Methanol was the VOC observed with the highest mixing ratio, with peak values up to 35 ppbv (Fig. 1) during the springsummer months suggesting high emissions from vegetation. This observation is consistent with previous results showing that increased emission occurs due to phenological modification of leaf tissues during leaf expansion, (Schade and Goldstein, 2002; Huve et al., 2007; Fall, 2003), and oxidative stress (Karl et al., 2001; Loreto et al., 2006), as a result of pectin demethylation when cell walls elongate during leaf expansion (Fall and Benson, 1996; Galbally and Kirstine, 2002), with plant growth recognized as the primary global source of methanol to the atmosphere (Galbally and Kirstine, 2002). In the diurnal cycle of gradient concentration shown in Fig. 2 for the winter and summer period, a slight gradient is visible in the morning between $9 \mathrm{AM}$ and $11 \mathrm{AM}$ during summer. The gradient is less visible during the central hours of the day, although these are the hours when maximum fluxes were recorded, rising up to a summer time average of $2 \mathrm{nmol} \mathrm{m}^{-2} \mathrm{~s}^{-1}$ (Fig. 5). Higher fluxes of methanol

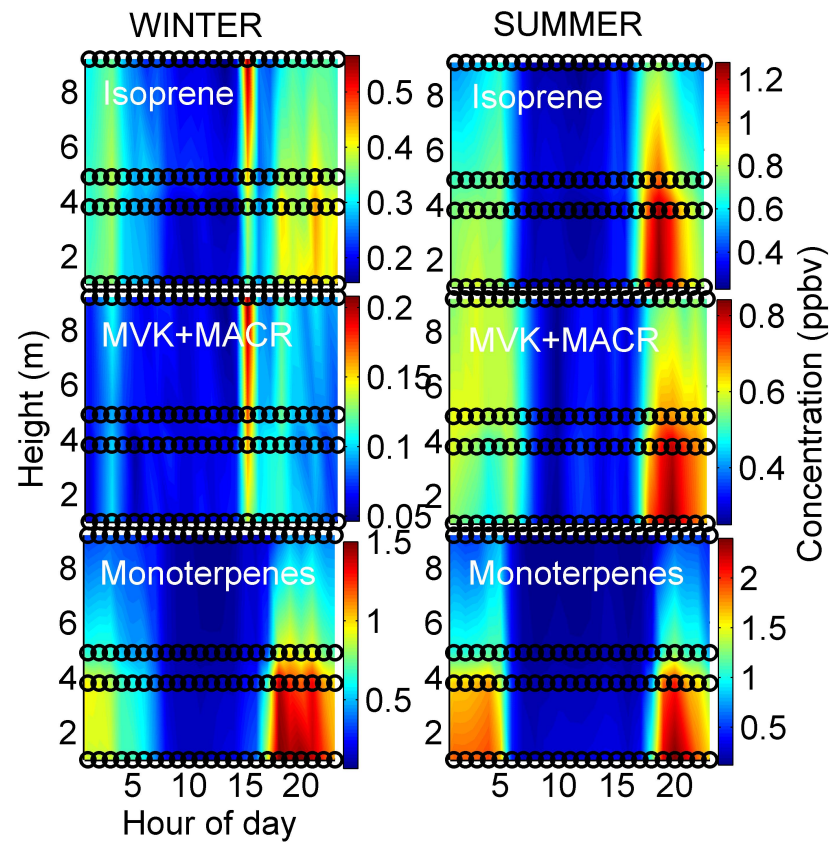

Fig. 3. Hourly average winter (DOY 37-80) and summer (DOY 172-274) vertical profiles of the major isoprenoid species measured by PTRMS (isoprene, sum of isoprene oxidation products methylvinyl-ketone and metachrolein, and sum of monoterpenes) within $(1 \mathrm{~m}, 3.76 \mathrm{~m})$ and above $(4.85 \mathrm{~m}$ and $9.18 \mathrm{~m})$ the orange orchard canopy (circles indicate measurement heights).

during mid-day hours have been previously described, with light-dependent emissions (Huve et al., 2007), and evidence of newly assimilated carbon re-emitted as methanol exhibiting a temperature dependence (Folkers et al., 2008, Fares et al., 2011). Strong nocturnal gradients decreasing from above down to the canopy suggest that some deposition occurs at night. This may be explained by the presence of dew on leaves, which we measured using sensors for leaf humidity (data not shown). Previous research (Karl et al., 2004) showed that deposition on wet leaves can be responsible for a large percentage of total deposition, the latter enhanced by hydrolytic reactions (Jayne et al., 1992). Despite this deposition process at night, it was difficult to detect a negative flux at night with the eddy covariance system (Fig. 5) because of the low turbulence which caused systematic underestimation of nighttime fluxes. Therefore most of the night measurements have been discarded due to low atmospheric turbulence $\left(u^{*}<0.15 \mathrm{~m} \mathrm{~s}^{-1}\right)$. Some positive gradients, however, were evident in the early evening hours (7:00 p.m.11:00 p.m.), in particular in the summer period. At these hours leaves are not wet and a foliar emission may be generated since methanol is produced during tissue expansion. This positive gradient from the canopy to the atmosphere in the early evening was less visible for the winter period, when there was greater water condensation on leaf surfaces (data not shown), especially during the night hours, and decreased 


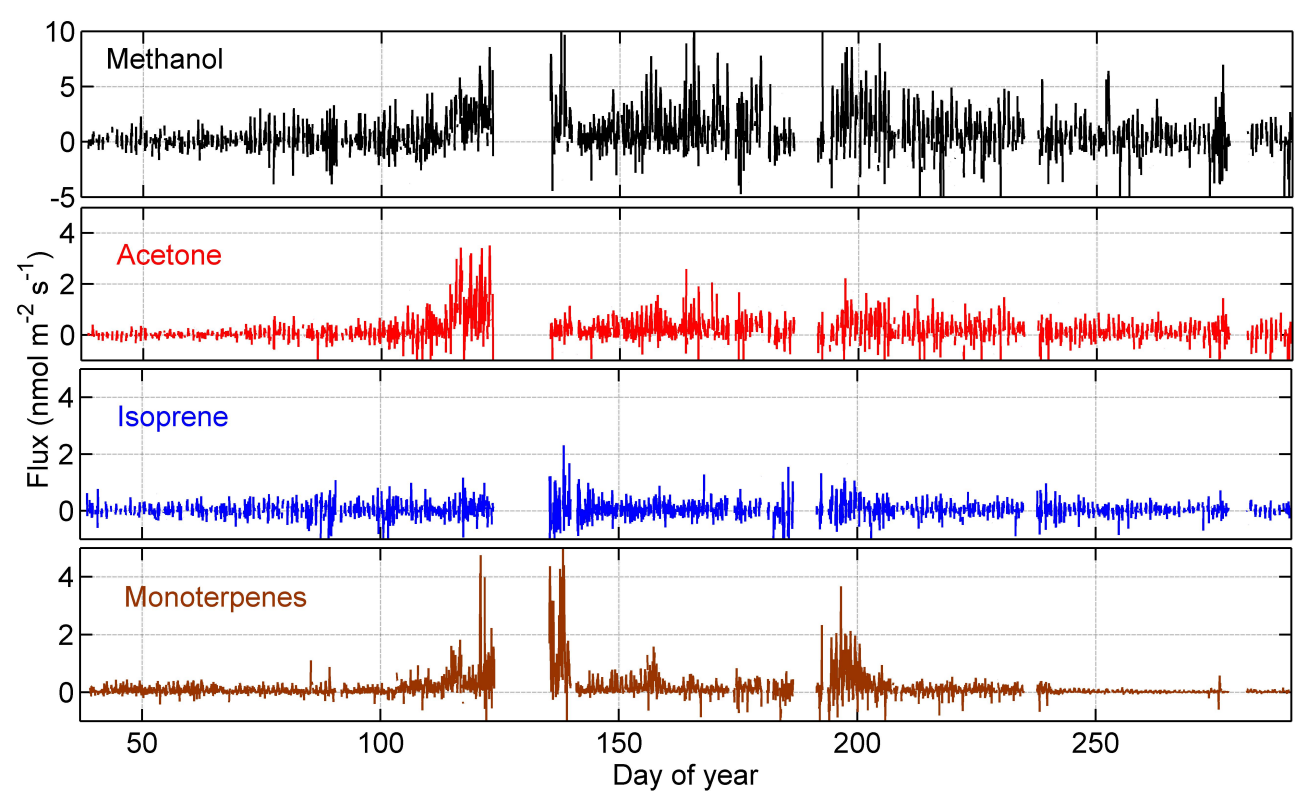

Fig. 4. Fluxes of the major BVOC species measured hourly by PTRMS Eddy Covariance at the Citrus site between February and November 2010 .

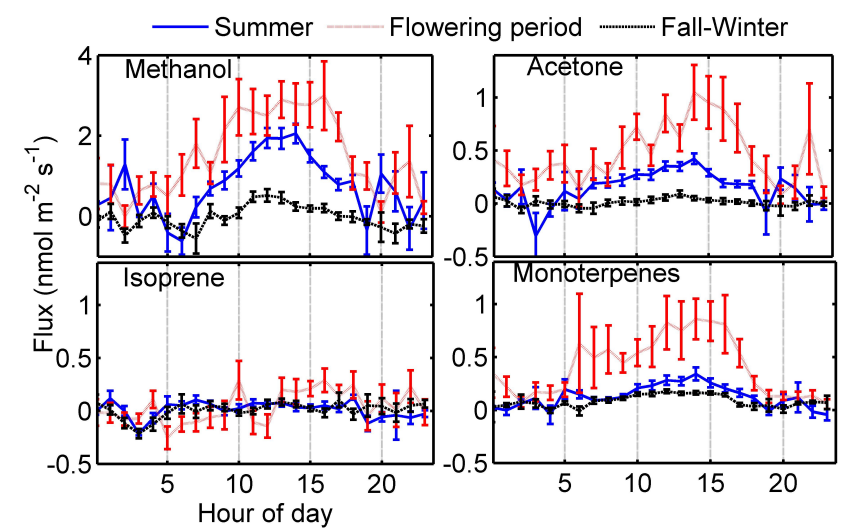

Fig. 5. Hourly average fluxes of BVOC species measured by PTRMS at the Citrus site during winter (black dashed line, DOY 37-80), flowering (red dotted line, DOY 130 to 140) and summer (blue line, DOY 172-274) periods. The error bars indicated Standard Deviation.

rates of biosynthesis in pathways for methanol formation (e.g. decrease in plant growth and photosynthesis) occurred. Flowering has been shown to produce a burst of terpenic and non-terpenic compounds (Arey et al., 1991, Ciccioli et al., 1999; Fares et al., 2011), and we observed an increase of ambient concentrations up to $35 \mathrm{ppb}$ and emission fluxes above $3 \mathrm{nmol} \mathrm{m}^{-2} \mathrm{~s}^{-1}$, in agreement with branch enclosure studies (Fares et al., 2011), where in the latter case the BEF was about two times higher (Table 2), and there was a decoupling of emissions from photosynthesis. Both of these results clearly show an increase of emission during flowering, but it is difficult to compare the branch enclosure and field studies quantitatively because the abundance and stage of flowering varied.

\subsubsection{Acetaldehyde and acetone}

An estimate of global emission for acetaldehyde similar to that for acetone was recently reported by Millet et al. (2009). The good correlation of acetaldehyde vs. acetone concentrations (slope $=1.1, R^{2}=0.8$ ) confirms a similar origin of these compounds, as previously observed (Karl et al., 2003; Schade and Goldstein, 2002). The physicochemical properties of these two organic compounds differ in terms of the reactivity in the liquid phase thus affecting their solubilities and Henry's law constants (Noziere and Riemer, 2003), with acetone being less reactive than acetaldeyde (Duncan et al., 1999). Acetaldehyde and acetone were also measured in concentrations up to $15 \mathrm{ppb}$ during the flowering period (Fig. 1), with ambient concentrations of each of these compounds equal to about one half of methanol. The orchard was a source of acetone during summer, with a visible positive gradient in the early evening, and became neutral or a slight sink during winter (Fig. 5). Although we did not directly measure acetaldehyde fluxes, a qualitative interpretation of Fig. 2 suggests that the emission dynamics could be similar to that for acetone, thus suggesting that the orchard can be an acetaldehyde source.

Acetone is the most abundant ketone in the atmosphere (Koppmann and Wildt, 2007), released during senescence (de Gouw et al., 1999) and oxidative stress in plants (e.g. from ozone) (Cojocariu et al., 2005), with global emissions estimated at $95 \mathrm{Tg} \mathrm{yr}^{-1}$ (Jacob et al., 2002). Acetone is another OVOC emitted by citrus leaves that also forms 
in the atmosphere through oxidation processes. We directly measured acetone fluxes with eddy covariance (Table 1, Figs. 4-5). Flowering significantly increased acetone emission, as shown from the enhanced atmospheric concentrations and the hourly fluxes (Figs. 1-5), reaching levels up to $2 \mathrm{nmol} \mathrm{m}^{-2} \mathrm{~s}^{-1}$, a value about two times higher than the typical summer emissions. A minor deposition of acetone is evident as a small gradient in Figure 2 for the late night/early morning in summer. This nocturnal transition from source to sink of methanol may also suggest that a compensation point exists for the citrus canopy, under the condition in which above a certain atmospheric concentration the canopy becomes a sink. This phenomenon has been reported also in previous studies in the field (Jardine et al., 2008; Karl et al., 2005) and in laboratory experiments (Seco et al., 2007). In this study, looking at this source/sink dynamics for the all measuring period, acetone compensation point seemed to be around $3.5 \mathrm{ppb}$, a concentration reached at the start of the flowering period (around DOY 130) until the end of the summer. We explain the late night/early morning sink as deposition on wet leaves and soil, since dew formation on leaves was recorded (data not shown). Overall, day fluxes are much larger than nocturnal deposition, and our results agree with previous research which found that rural areas can have significant sources of acetone (Goldan et al., 1995; Riemer et al., 1998; Ciccioli et al., 1999; Schade and Goldstein 2001).

Acetaldehyde is emitted by leaves in large quantities during and after abiotic stresses (Fall et al., 1999; Loreto et al., 2006). Acetaldehyde in particular has been shown to be emitted by Citrus plants especially during flowering (Fares et al., 2011), although this compound is also produced by atmospheric oxidation processes (e.g. photooxidation of linalool), as described by Ciccioli et al. (1999), and Smith et al. (1996). This last formation source may justify the high amount we recorded in the field especially relative to monoterpenes, in comparison with the minor amount measured in branch enclosures, where reactivity in the gas phase was minimized (Fares et al., 2011).

BEF variations between winter, spring (flowering season) and summer for methanol and acetone (Table 2), showed higher values during flowering, probably due to enhanced pectin demethylation (Galbally and Kirstine, 2002) during organ development and flowering. A seasonal variation of BEF was also observed for an oak forest (Geron et al., 2000), a hardwood forest (Karl et al., 2003) and a pine forest (Schade and Goldstein, 2006; Holzinger et al., 2006). In particular, Karl et al. (2003) observed a BEF for acetone higher in fall, ascribing this major emission to decaying plant material, and Schade and Goldstein (2006) saw enhanced emissions of acetone and methanol in the spring during budbreak and elongation of pine needles.

\subsection{Isoprenoid concentrations and fluxes}

\subsubsection{Isoprene}

Isoprene was measured in relatively low concentrations, rarely above 2 ppbv except during the flowering season, when nocturnal peak concentrations increased to 5 ppbv (Fig. 1). Isoprene fluxes were negligible in all seasons (Fig. 5), in agreement with previous findings showing that orange is not a high isoprene emitter (Winer et al., 1992; Ciccioli et al., 1999; Fares et al., 2011). During the winter period, the orchard was acting more as an isoprene sink based on our observations of the concentration gradients (Fig. 3). An evident deposition phenomenon is occurring at $\sim 4$ p.m. The analysis of the wind rose showed in Fares et al. (2012) for the same experimental site with prevailing wind directions from west suggests that isoprene was transported to the orchard through advection plumes from a source far away from our measuring footprint. likely oak trees in the nearby urban areas of Farmerville and Exeter. Similar to isoprene, its primary oxidation products methyl-vinyl-ketone and methacrolein (MVK+MACR) follow the same pattern during the winter and in summer. Deposition of MVK+MACR has been recently observed by Karl et al. (2010) in a tropical forest, as a result of uptake and degradation inside leaves by enzyme activity. During summer, both isoprene and MVK+MACR followed the same dynamics, with a notable positive gradient suggesting emission from the ground level to above the canopy in the early evening hours. Despite this positive gradient, the low turbulence did not allow measurement of a significant flux during those hours, but the observed gradient suggests that a minimal production of isoprene occurs in the early night hours. This may be explained by the consumption at night of residual substrate pools (e.g. dimethyl-allyldi-phosphate) produced during photosynthesis in the light hours, although a strong post-illumination decay in isoprene emission has been described to happen in a few minutes (Rasulov et al., 2009) which does not correspond to the time delay observed in our study $(2-3 \mathrm{~h})$. The positive fluxes of MVK+MACR during the same hours are consistent with recent findings (Jardine et al., 2012) that isoprene oxidation products can be emitted directly from leaves as result of intercellular oxidation of isoprene with ROS (Reactive Oxygen Species).

\subsubsection{Monoterpenes}

Monoterpenes were the isoprenoid emissions observed in the highest abundance. Both in winter and in summer, a positive gradient from the ground to above the canopy was detected (Fig. 3), although fluxes were quite small $\left(<0.3 \mathrm{nmol} \mathrm{m}^{-2} \mathrm{~s}^{-1}\right)$. Soil and litter may significantly contribute to monoterpene emissions, in part due to the organic matter degradation processes in soils, and in part due to biomass wounding and decay following harvesting or 

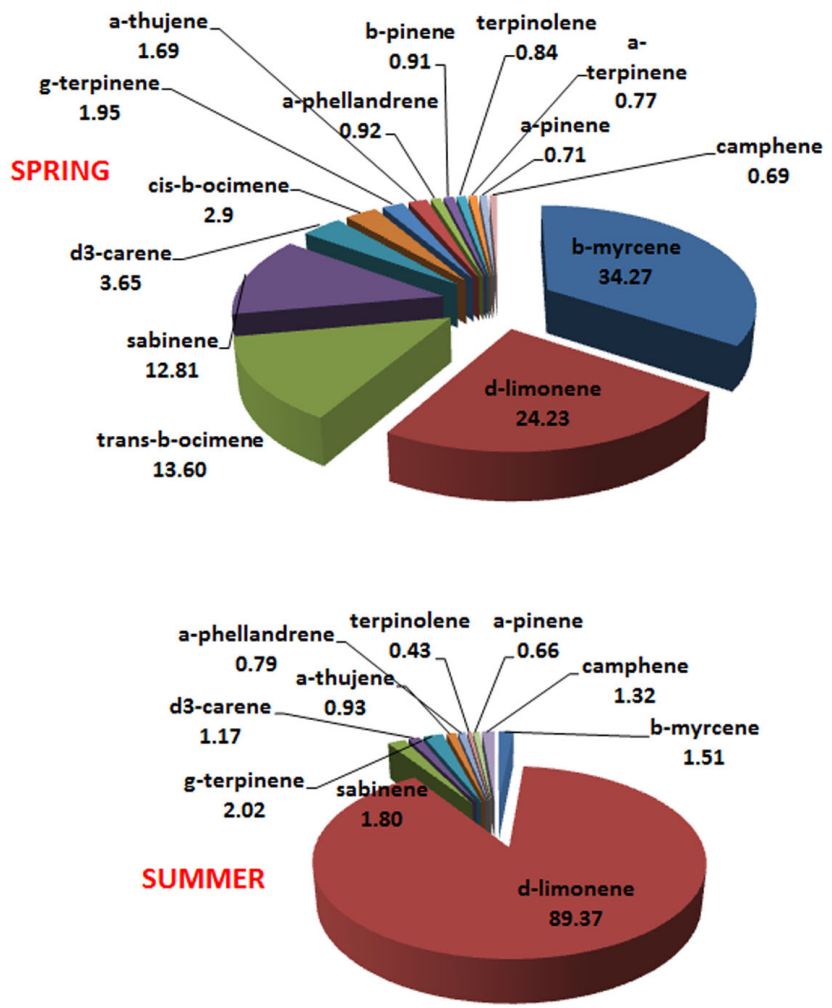

Fig. 6. Pie chart showing the percent distribution of monoterpene species measured with GC-MS during the spring flowering (25 April to 5 May) and summer (11 to 24 August) periods. Percents were calculated as the total fraction of the mass observed over the period of the measurements.

pruning operations. Consistent with this suggestion, in a study of limonene fluxes in a navel orange orchard, soils have been demonstrated to be a major source (Ciccioli et al., 1999).

In our study, both summer and winter fluxes of monoterpenes were quite low, with mid-day values of $\sim 0.4 \mathrm{nmol} \mathrm{m}^{-2} \mathrm{~s}^{-1}$. Much higher monoterpene fluxes were observed during the flowering period, when the obvious smell of terpenes permeated the whole region, consistent with previously reported findings in greenhouse-based studies with plant enclosures (Fares et al., 2011). We also measured changes in the ambient concentration of monoterpene species between spring (flowering) and summer periods (Fig. 6). During the flowering period, beta-myrcene, dlimonene, trans-beta-ocimene and sabinene were the most abundant monoterpene species, while monoterpenes in summer were dominated by d-limonene. Changes in emission blend during flowering were also observed in branch enclosure studies (Fares et al., 2011), confirming that certain biosynthetic pathways are triggered to attract pollinators. However for the enclosure studies, during flowering the dominant monoterpenes were the cis and trans forms of beta-ocimene, while during summer we measured preva- lently beta-myrcene. These differences suggest that the measured monoterpenes in the atmosphere may have a biogenic signature but not necessary attributed to Valencia orange. Advective air masses from nearby cultivations of Murcot mandarin may have contributed to the measured monoterpene concentrations, and indeed we observed limonene emissions from Murcot mandarin in the enclosure studies. Another reason for the discrepancy may lie in the use of Navel orange for the enclosure studies, which may have different emissions than Valencia orange. We also want to point out that chemical reaction with ozone in the gas-phase is an important phenomenon in the California central valley, when ozone concentrations often exceed $100 \mathrm{ppb}$, and limonene chemical lifetime is longer than other monoterpenes (e.g. myrcene), as pointed out in previous studies (Fares et al., 2010), supporting the hypothesis that certain monoterpenes may have reacted in the atmosphere before being measured. This point is particularly important for sesquiterpenes, and is discussed in the next section.

The monoterpene content in leaves and the cuticular wax thickness may explain the lack of large seasonal change in monoterpene emissions between winter and summer. Terpene accumulation within leaves was highest in summer, followed by spring, with the lowest levels in fall and winter (Fig. 7a). Leaf waxes, represented by long-chain aliphatic alkanes, especially $\mathrm{C}_{31} \mathrm{H}_{64}$ and $\mathrm{C}_{33} \mathrm{H}_{68}$, showed the same seasonal pattern (Fig. 7b). A positive linear relationship was observed between the total monoterpene hydrocarbon concentration (y) and cuticle wax concentrations (x, represented by long-chain aliphatic compounds) $\left(R^{2}=0.75, y=-9.27+\right.$ $3.72 x)$ as well as between the total monoterpene hydrocarbons $(y)$ and 1-dodecanol $(x)$ (the only aliphatic alcohol detected) $\left(R^{2}=0.86, y=5.82+25.80 x\right)$. These results suggest that despite higher synthesis and thereby accumulation of terpenes during the warmest months, cuticle waxes, which are known to accumulate during summer to minimize water losses, result in a limitation of terpene emissions to the atmosphere, as noted in Ormeño et al. (2011).

During flowering, ambient concentrations of monoterpenes reached their maximum with nocturnal values up to $10 \mathrm{ppb}$ (Fig. 1), and fluxes reached the maximum annual levels in agreement with branch-level experiments in the greenhouse (Fares et al., 2011) and previous research (Ciccioli et al., 1999; Hansen and Seufert 2003; Arey et al., 1991), showing values during the day close to $1.8 \mathrm{nmol} \mathrm{m}^{-2} \mathrm{~s}^{-1}$. In agreement with the enclosure experiment (Fares et al 2011), $\mathrm{BEF}$ for monoterpenes were much higher during the flowering period than in summer $\left(1.31\right.$ and $0.13 \mathrm{nmol} \mathrm{m}^{-2} \mathrm{~s}^{-1}$, respectively, Table 2), suggesting that in spring, the biosynthesis of monoterpenes is enhanced due to both emissions released by flowers and biotic damage to leaves. It has been previously shown that certain monoterpene species (e.g. ocimene, figure 6) are emitted in large amount during flowering, to attract pollinators (Dudareva and Pickersky 2000) and due to insect damage (Pare and Tumlinson 1999). The 

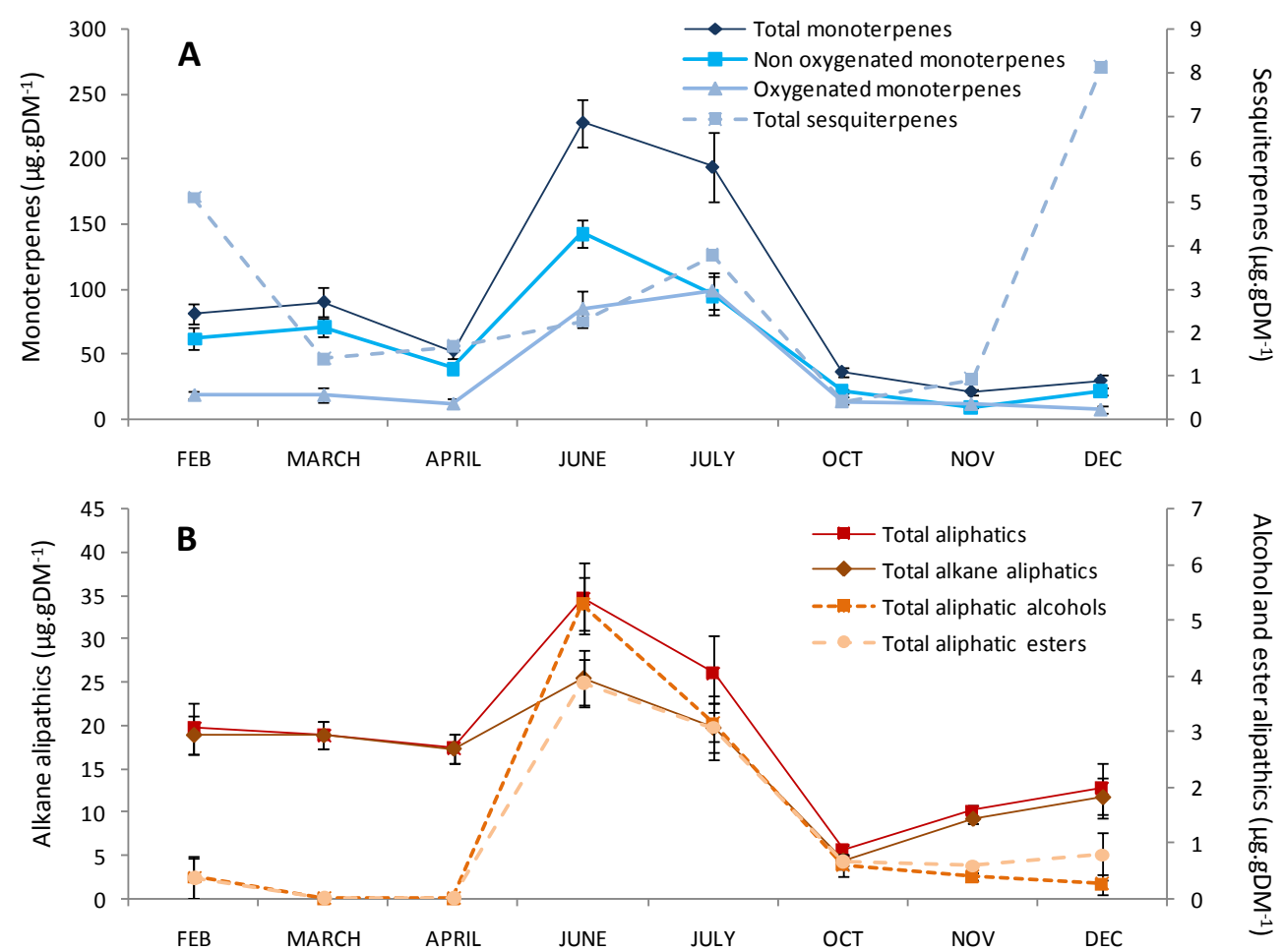

Fig. 7. Seasonal course of (A) leaf BVOC concentration ( $80 \%$ monoterpene compounds) and (B) cuticle waxes ( $88 \%$ alkane-alipathic compounds). Values shown are the average of ten trees each month and bars denote the standard error.

magnitude of BEF from enclosure experiments was almost five times higher than field-based BEF. This may be explained in part by a possible overestimation of canopy-scale fluxes obtained by simply scaling-up enclosure-derived BEF by LAI and considering shaded leaves to contribute as much to emissions as light-exposed leaves. Another reason for this discrepancy in flux magnitude could be that potted and wellwatered trees in the greenhouse did not experience the high temperature and ozone stress which occurs in the Central Valley, with limitations in plant water as shown by vapour pressure deficit occurring even in presence of sufficient irrigation. Our results highlight the importance of calculating $\mathrm{BEF}$ in different seasons for a proper parameterization of emission models, as also suggested through measurements by Goldstein et al. (1998), Keenan et al (2009) and Niinemets et al. (2010).

\subsection{C-6 oxygenated compounds}

Concentrations of aldehydes and alcohols containing 6 carbon atoms (hexenals, hexenols, and hexanals) were measured by the PTRMS at $\mathrm{m} / \mathrm{z} 83$ and $\mathrm{m} / \mathrm{z}$ 99, as also reported in Davison et al. (2009). Hourly gradient concentrations for the winter and summer season are summarized in Fig. 8 . The absence of a gradient from the ground to above the canopy during winter suggests that no significant emission took place during the cold period, but rather a strong deposition occurred in the afternoon at $\sim 3$ p.m., so that we can hypothesize transport of emissions from remote sources to the site, similarly to what observed for isoprene and its oxidation products. During summer, hexanals and hexenols $(\mathrm{m} / \mathrm{z}, 83)$ and hexenals $(\mathrm{m} / \mathrm{z}$ 99) had a diurnal pattern similar to monoterpenes, with gradients from the soil to above the canopy indicating emissions. Although we did not measure fluxes, we hypothesize that the orange orchards are a source of these so called "C-6 compounds" or "green leaf volatiles" to the atmosphere. C- 6 compounds are formed of 6 carbon atoms and can originate from denaturation of membrane lipids, predominantly from unsaturated fatty acids, under the action of lipoxygenase and hydroperoxide lyase enzymes (Hatanaka 1993). Emissions have been record in response to wounding (Fall et al., 2003, Loreto et al., 2007) and exposure to ozone (Heiden et al., 2003). Flowering and wounding due to harvesting (DOY 130-140) apparently caused high concentrations $(>4 \mathrm{ppb})$ recorded at night during the flowering and harvesting periods (Fig. 1).

\subsection{Aromatic compounds}

Concentrations of aromatic compounds have been measured with PTRMS at $\mathrm{m} / z$ 79, 93, 107, and could be likely ascribed to Benzene, toluene + p-cymene, and benzaldehyde+ xylenes, respectively. Since a detailed analysis with GC/MS is not available for these compounds, we cannot discriminate 
between isobaric compounds (e.g. relative abundance of toluene vs. p-cymene, and benzaldehyde vs xylenes). These benzenoid compounds are typically assumed to originate from anthropogenic sources such as fuel use and combustion. Previous research in urban areas has shown how peaks of these compounds are recorded during high vehicular traffic, making these compounds good proxies for anthropogenic fuel emissions. Recent findings (Misztal et al., 2012, in preparation) support the idea that plants can also produce and emit small amounts of benzenoid compounds. While these fluxes are very small and expected to be negligible in terms of their impact on atmospheric chemistry in a fairly polluted environment such as the San Joaquin Valley, the benzenoid emissions from plants are very interesting and may play a role in plant signalling and trophic interactions.

We show vertical gradient concentrations of $\mathrm{m} / \mathrm{z} 79,93$, 107 (Fig. 9), for winter, summer, and the flowering period. In all seasons, we identify in the early evening a clear positive gradient indicative of emissions, similar to that observed for isoprenoids, which causes us to hypothesize biogenic sources for these compounds. This emission pattern is quite evident for the summer season, and the figure includes a significant number of averaged days $(\mathrm{N}>80)$. During the flowering period, concentrations were higher, in agreement with previous finding reporting that during flowering the biosynthetic pathways for benzenoid compounds is triggered by up-regulating genes of the shikimate pathway (van Schie et al., 2006). Benzenoic compounds can play a role, in addition to certain isoprenoids (e.g. linalool, ocimenes), in attracting pollinators (Dudareva et al., 2004). Interestingly, a source of $\mathrm{m} / \mathrm{z} 107$ seems to be located in the upper part of the canopy based on the observed vertical gradients, just where a higher density of flowers was observed, thus suggesting a floral origin. Future research is needed to assess whether biogenic emissions of these compounds are significant compared to anthropogenic emissions, and to better determine the biological significance of these emissions.

\subsection{Evidence for unmeasured additional BVOC emissions}

The PTRMS technology employed in this study allowed us to measure fluxes of major atmospheric VOC components for one full year. Together with fluxes of selected compounds, the PTRMS measured concentrations and vertical gradients of other important VOC which we attribute to a biogenic origin, described in the sections above. We want to mention that during an intensive summer campaign, a PTR-TOF-MS (Proton Transfer Reaction Time of Flight Mass Spectrometer) was deployed at the field site, allowing for one month of flux measurements for an extended suite of compounds (Park. et al.2012). While the PTR-TOFMS showed excellent agreement with the measurement of the compounds observed with PTRMS, it allowed us to measure a multitude of additional masses which significantly increased the observed total bio- genic emissions from the orchard. Thus, the fluxes reported here can indeed explain the seasonality of the major BVOC emitted from vegetation, although we are confident the reported compounds do not represent the totality of emissions.

Among the unmeasured compounds are sesquiterpenes. These compounds are a very important class of isoprenoids which have been identified when emissions from oranges were measured with branch enclosures (Fares et al., 2011, Ciccioli et al., 1999). Sesquiterpenes are very reactive with tropospheric ozone (Atkinson and Arey, 2003) and therefore have very short atmospheric lifetimes. $\beta$-caryophyllene is the main sesquiterpene emitted from Citrus (Fares et al., 2011; Ciccioli et al., 1999), and we estimated an atmospheric lifetime of $\sim 30-80 \mathrm{~s}$ when ozone concentrations are between 40 and $100 \mathrm{ppb}$, and peak ozone was often measured at the orchard at levels from 70 to almost $120 \mathrm{ppb}$ in summer during the study. We tried to minimize the residence time of the air in the sampling line $(\sim 2.2 \mathrm{~s})$, but the high reactivity with ozone, the poor transmission efficiency of $\beta$-caryophyllene in the PTRMS, and likely losses in our sampling lines resulted in very low concentration measurements for these compounds ( $0.05 \mathrm{ppb}$ during summer mid-day), and these conditions preclude us from providing a quantitative analysis of these emissions. A discrepancy in magnitude between $\beta$ caryophyllene measured in branch enclosures and in the field at the whole canopy scale was also reported by Ciccioli et al. (1999), with enclosure fluxes being very high, even higher than monoterpenes, similar to what we found in our greenhouse enclosure experiments (Fares et al., 2011). In the field, Ciccioli et al. using the relaxed eddy accumulation (REA) technique observed low fluxes of $\beta$-caryophyllene in comparison to the enclosure measurement, and justified this by the high estimated resident time during the central hours of the day (360-480 s) of the molecule in the air space between the soil and the sensor above the canopy. Turbulence at our site was low, similar to that observed by Ciccioli et al.; therefore, it is reasonable to hypothesize a similarly long residence time for $\beta$-caryophyllene relative to its atmospheric lifetime. Our results therefore suggest that models to predict sesquiterpene emissions from BEF estimated using leaf/branch enclosure data from the controlled greenhouse experiments may be a better and more quantitative approach than what we could achieve in the field, where oxidant (ozone) levels were high and sesquiterpene lifetimes were very short.

\section{Conclusions}

We measured concentrations and fluxes of an important fraction of BVOC emitted from a Valencia orange (Citrus sinensis) orchard continuously for one year. This Citrus species is extensively cultivated in California and in many other regions of Mediterranean climate. Our observations were focused on the most abundant BVOC which we previously identified 
using enclosures of plants grown in greenhouses under optimal conditions.

Oxygenated VOC (methanol, acetaldehyde, and acetone) and monoterpenes were the major BVOC emissions we observed from oranges in the field. We found gradients in concentrations from the soil to above the canopy, especially at night, when the atmospheric boundary layer is low and vertical turbulence is minimized, suggesting that fluxes occur even at night, but cannot be quantitatively described in our study due to methodological limitations of the eddy covariance technique when turbulence is low. We found high concentrations of monoterpenes stored inside leaves during summer coinciding with lower emissions and high cuticular wax content; thus, we hypothesize limitations to gaseous emissions because of the enhanced physical barrier.

Isoprene and its oxidation products, methyl-vinyl-ketone and methacrolein, were shown to be emitted in very small amounts in the late afternoon, and occasionally deposited at night (again in small amounts) based on observation of their vertical profiles. Our observations of a positive gradient of these oxidation compounds supports recent findings (Jardine et al., 2012) that a fraction of these compounds may be formed inside leaves from reaction of isoprene with reactive oxygen species (ROS).

In this study, we reported atmospheric concentrations of other important volatile compounds which may have a biogenic source. Both aromatic and C6 oxygenated compounds had positive concentration gradients from the ground to above the canopy, demonstrating that orchards emit small amounts of these compounds. Although further research is necessary to determine the importance of biogenic emissions of these compounds for atmospheric chemistry in comparison with anthropogenic emissions in this environment, they may be important for pollinator attraction and other ecological interactions.

The full year of measurements allowed us to compare BEFs for different seasons. We found that during flowering BEFs were consistently higher for most BVOC studied. This seasonality of BVOC emissions from crops should be considered in global and statewide emission models, and the largest annual fraction of emissions from Central Valley crops that flower in springtime is likely to occur during that period. Our results should be useful in atmospheric chemistry models to estimate whether BVOC emitted from these crop species play a significant role in regional photochemistry, especially when Citrus plantations are close to urban areas as in the Central Valley of California, where BVOC emissions can combine with anthropogenic emissions to contribute to ozone and secondary aerosol production.

Acknowledgements. We thank Jim and Milo Gorden for hosting this study in their orchard. Beth Grafton-Cardwell, Kurt Schmidt, and Dan Seymore of the UC Lindcove Station, and Rick Ramirez of UC Cooperative Extension provided critical support. We also thank Neil O'Connell and Craig Kallsen of UC Cooperative Extension as well as Ya-Ting Liu, Caroline Lecareux and Stephane Greff from Aix Marseille University for their assistance on extraction and analysis of terpenes and cuticle waxes in leaves. We gratefully acknowledge support for this research by the Citrus Research Board, the California Air Resources Board, and the European Commission Marie Curie IOF 2008 project CITROVOC.

Edited by: J. Rinne

\section{References}

Adams, R. P.: Gas Chromatograph/Mass Spectrometry. In Identification of essential oil components by Gas Chromatography/Mass Spectrometry; Allured Publishing Corporation: Carol Stream, IL; p. 804, 2007.

Arey, J., Corchnoy, S. B., and Atkinson, R.: Emission of linalool from Valencia orange blossoms and its observation in ambient air, Atmos. Environ., 25, 1377-1381, 1991.

Atkinson, R., and Arey, J.: Gas-phase tropospheric chemistry of biogenic volatile organic compounds: a review, Atmos. Environ., 37, 197-S219, 2003.

Bamberger, I., Hörtnagl, L., Schnitzhofer, R., Graus, M., Ruuskanen, T. M., Müller, M., Dunkl, J., Wohlfahrt, G., and Hansel, A.: BVOC fluxes above mountain grassland, Biogeosciences, 7, 1413-1424, doi:10.5194/bg-7-1413-2010, 2010.

Bianco, L., Djalalova, I. V., King, C. W., and Wilczak, J. W.: Diurnal Evolution and Annual Variability of Boundary-Layer Height and Its Correlation to Other Meteorological Variables in California's Central Valley, Bound.-Layer Meteorol., 140, 491-511, doi:10.1007/s10546-011-9622-4, 2011.

Bouvier-Brown, N. C., Goldstein, A. H., Worton, D. R., Matross, D. M., Gilman, J. B., Kuster, W. C., Welsh-Bon, D., Warneke, C., de Gouw, J. A., Cahill, T. M., and Holzinger, R.: Methyl chavicol: characterization of its biogenic emission rate, abundance, and oxidation products in the atmosphere, Atmos. Chem. Phys., 9, 2061-2074, doi:10.5194/acp-9-2061-2009, 2009.

Chameides, W. L., Lindsay, R. W., Richardson, J., and Kiang, C. S.: The role of biogenic hydrocarbons in urban photochemical smog: Atlanta as a case study. Science 241, 1473-1475, 1988.

Ciccioli, P., Brancaleoni, E., Frattoni, M., Di Palo, V., Valentini, R., Tirone, G., Seufert, G., Bertin, N., Hansen, U., Csik, O., Lenz, R., and Sharma, M.: Emission of reactive terpene compounds from orange orchards and their removal by within-canopy processes, J. Geophys. Res., 104, 8077-8094, 1999.

Cojocariu, C., Esher, P., Heinz-Haberle, K., Matyssek, R., Rennemberg, H., and Kreuzwieser, J.: The effect of ozone on the emission of carbonyls from leaves of adult Fagus sylvatica, Plant Cell Environ., 28, 603-611, 2005.

Davison, B., Taipale, R., Langford, B., Misztal, P., Fares, S., Matteucci, G., Loreto, F., Cape, J. N., Rinne, J., and Hewitt, C. N.: Concentrations and fluxes of biogenic volatile organic compounds above a Mediterranean macchia ecosystem in western Italy, Biogeosciences, 6, 1655-1670, doi:10.5194/bg-6-16552009, 2009.

De Gouw, J. A., Howard, C. J., Custer T. J., and Fall, R.: Emissions of volatile organic compounds from cut grass and clover are enhanced during the drying process, Geophys. Res. Lett. 26, 811-814, 1999. 
Dudareva, N., Pichersky, E., Gershenzon, J.: Biochemistry of plant volatiles. Plant Physiology 135, 1893-1902, 2004.

Duhl, T. R., Helmig, D., and Guenther, A.: Sesquiterpene emissions from vegetation: a review, Biogeosciences, 5, 761-777, doi:10.5194/bg-5-761-2008, 2008.

Duncan, J. L., Schindler, L. R., and Roberts, J. T.: Chemistry at and near the surface of liquid sulfuric acid: A kinetic, thermodynamic, and mechanistic analysis of heterogeneous reactions of acetone, J. Phys. Chem. B, 103, 7247-7259, 1999.

Dudareva, N. and Pichersky, E.: Biochemical and molecular aspects of floral scents, Plant Physiol., 122, 627-634, 2000.

EPA.: Reference list of deleterious effect of ozone on human health, http://www.epa.gov/o3healthtraining/refsfigs.html\#refs, last access: 26 March 2011.

Fall, R.: Abundant oxygenates in the atmosphere: A biochemical perspective, Chem. Rev., 103, 4941-4951, 2003.

Fall, R. and Benson, A. A.: Leaf methanol - The simplest natural product from plants, Trends Plant Sci., 1, 296-301, 1996.

Fares, S., Park, J. H., Ormeno, E., Gentner, D. R., McKay, M., Loreto, F., Karlik, J., and Goldstein, A. H.: Ozone uptake by Citrus trees exposed to a range of ozone concentrations, Atmos. Environ., 44, 3404-3412, 2010.

Fares, S., Gentner, D. R., Park, J. H., Ormeno, E., Karlik, J., and Goldstein, A. H.: Biogenic emissions from Citrus species in California, Atmos. Environ., 45, 4557-4568., 2011.

Fares, S., Weber, R. J., Park, J. H., Gentner, D. R., Karlik, J., and Goldstein, A. H.: Ozone deposition to an orange orchard: Partitioning between stomatal and non-stomatal sinks, Environ. Poll., 169, 258-266, 2012.

Folkers, A., Huve, K., Ammann, C., Dindorf, T., Kesselmeier, J., Kleist, E., Kuhn, U., Uerlings, R., and Wildt, J.: Methanol emissions from deciduous tree species: dependence on temperature and light intensity, Plant Biol., 10, 65-75, 2008.

Foken, T. and Wichura, B.: Tools for quality assessment of surfacebased flux measurements, Agr. Forest Meteorol., 78, 83-105, 1996.

Galbally, I. E. and Kirstine, W.: The Production of Methanol by Flowering Plants and the Global Cycle of Methanol, J. Atmos. Chem., 43, 195-229, 2002.

Geron, C., Rasmussen, R., Arnts, R. R., and Guenther, A.: A review and synthesis of monoterpene speciation from forests in the United States, Atmos. Environ., 34, 1761-1781, 2000.

Goldan, P. D., Kuster, W. C., Fehsenfeld, F. C., and Montzka, S. A.: Hydrocarbon M easurements in the Southeastern United States - the Rural Oxidants in the Southern Environment (ROSE) Program, J. Geophys. Res., 100, 25945-25963, 1995.

Goldstein, A. H. and Galbally, I. E.: Known and unexplored organic constituents in the earth's atmosphere, Environ. Sci. Technol., 41, 1514-1521, 2007.

Goldstein, A. H. and Schade, G. W.: Quantifying biogenic and anthropogenic contributions to acetone mixing ratios in a rural environment, Atmos. Environ. 34, 4997-5006, 2000.

Guenther, A., Hewitt, C.N., Erickson, D., Fall, R., Geron, C., Graedel, T., Harley, P., Klinger, L., Lerdau, M., McKay, W.A., Pierce, T., Scholes, B., Steinbrecher, R., Tallamraju, R., Taylor, J., and Zimmerman, P.: A global model of natural volatile organic compounds emissions, J. Geophys. Res., 100, 8873-8892, 1995.

Hansen, U. and Seufert, G.: Terpenoid emission from Citrus sinensis (L.) Osbeck under drought stress, Physics and Chemistry of the Earth Part B - Hydrol. Ocean. Atmos., 24, 681-687, 1999.

Hatanaka A.: The biogeneration of green odour by green leaves, Phytochemistry 34, 1201-1218, 1993.

Heiden, A. C., Kobel, K., Langebartels, C., Schuh-Thomas, G., and Wildt J.: Emissions of oxygenated volatile organic compounds from plants, Part I: emissions from lipoxygenase activity, J. Atmos. Chem., 45, 143-172, 2003.

Henze, D. K. and Seinfeld, J. H.: Global secondary organic aerosol from isoprene oxidation, Geophys. Res. Lett., 33, L09812, doi:10.1029/2006GL025976, 2006.

Holzinger, R., Lee, A., Paw, K. T., and Goldstein, U. A. H.: Observations of oxidation products above a forest imply biogenic emissions of very reactive compounds, Atmos. Chem. Phys., 5, 67-75, doi:10.5194/acp-5-67-2005, 2005.

Holzinger, R., Lee, A., McKay, M., and Goldstein, A. H.: Seasonal variability of monoterpene emission factors for a ponderosa pine plantation in California, Atmos. Chem. Phys., 6, 1267-1274, doi:10.5194/acp-6-1267-2006, 2006.

Horst, T. W.: A simple formula for attenuation of eddy fluxes measured with first-order-response scalar sensors, Bound.-Layer Meteorol., 82, 219-233, 1997.

Hsieh, C. I., Katul, G., and Chi, T. W.: An approximate analytical model for footprint estimation of scalar fluxes in thermally stratified atmospheric flows, Adv. Water Resour., 23, 765-772, 2000.

Huve, K., Christ, M., Kleist, E., Niinemets, U., Uerlings, R., Walter, A., and Wildt, J.: Simultaneous growth and emission measurements demonstrate an interactive control of methanol release by leaf expansion and stomata, J. Exp. Bot. 58, 1783-1793, 2007.

Jacob, D. J., Field, B. D., Li, Q., Blake, D. R., de Gouw, J., Warneke, C., Hansel, A., Wisthaler, A., Singh, H. B., and Guenther, A.: Global budget of methanol: Constraints from atmospheric observations, J. Geophys. Res., 110, D08303, doi:10.1029/2004JD005172, 2005.

Jayne, J. T., Duan, S. X., Davidovits, P., Worsnop, D. R., Zahniser, M. S., and Kolb, C. E.: Uptake of gas-phase aldehydes by water surfaces, J. Phys. Chem., 96, 5452-5460, 1992.

Jardine, K., Harley, P., Karl, T., Guenther, A., Lerdau, M., and Mak, J. E.: Plant physiological and environmental controls over the exchange of acetaldehyde between forest canopies and the atmosphere, Biogeosciences, 5, 1559-1572, doi:10.5194/bg-5-15592008, 2008.

Jardine, K. J., Monson, R. K., Abrell, L., Saleska, S. R., Arneth, A., Jardine, A., Ishida, F. Y., Serrano, A. M. Y., Artaxo, P., Karl, T., Fares, S., Goldstein, A., Loreto, F., and Huxman, T.: Within-plant isoprene oxidation confirmed by direct emissions of oxidation products methyl vinyl ketone and methacrolein, Global Change Biol., 18, 973-984, doi:10.1111/j.1365-2486.2011.02610, 2012.

Kanakidou, M., Seinfeld, J. H., Pandis, S. N., Barnes, I., Dentener, F. J., Facchini, M. C., Van Dingenen, R., Ervens, B., Nenes, A., Nielsen, C. J., Swietlicki, E., Putaud, J. P., Balkanski, Y., Fuzzi, S., Horth, J., Moortgat, G. K., Winterhalter, R., Myhre, C. E. L., Tsigaridis, K., Vignati, E., Stephanou, E. G., and Wilson, J.: Organic aerosol and global climate modelling: a review, Atmos. Chem. Phys., 5, 1053-1123, doi:10.5194/acp-5-1053-2005, 2005.

Karl, T., Guenther, A., Lindinger, C., Jordan, A., Fall, R., and Lindinger, W.: Eddy covariance measurements of oxygenated volatile organic compound fluxes from crop harvesting using a redesigned proton-transfer-reaction mass spectrometer, J. Geo- 
phys. Res.-Atmos., 106, 24157-24167, 2001.

Karl, T. G., Spirig, C., Rinne, J., Stroud, C., Prevost, P., Greenberg, J., Fall, R., and Guenther, A.: Virtual disjunct eddy covariance measurements of organic compound fluxes from a subalpine forest using proton transfer reaction mass spectrometry, Atmos. Chem. Phys., 2, 279-291, doi:10.5194/acp-2-279-2002, 2002.

Karl, T., A. Guenther, C. Spirig, A. Hansel, and Fall, R.: Seasonal variation of biogenic VOC emissions above a mixed hardwood forest in northern Michigan, Geophys. Res. Lett., 30, 2186, doi:10.1029/2003GL018432, 2003.

Karl, T., Potosnak, M., and Guenther, A.: Exchange processes of volatile organic compounds above a tropical rain forest: Implications for modeling tropospheric chemistry above dense vegetation. J. Geophys. Res., 109, doi:10.1029/2004JD004738, D18306, 2004.

Karl, T., Harley, P., Guenther, A., Rasmussen, R., Baker, B., Jardine, K., and Nemitz, E.: The bi-directional exchange of oxygenated VOCs between a loblolly pine (Pinus taeda) plantation and the atmosphere, Atmos. Chem. Phys., 5, 3015-3031, doi:10.5194/acp5-3015-2005, 2005.

Keenan, T., Niinemets, Ü., Sabate, S., Gracia, C., and Peñuelas, J.: Seasonality of monoterpene emission potentials in Quercus ilex and Pinus pinea: Implications for regional VOC emissions modeling, J. Geophys. Res., 114, D22202, doi:10.1029/2009JD011904, 2009.

Kesselmeier, J. and Staudt, M..: Biogenic volatile organic compounds (VOC): an overview on emission, physiology and ecology, J. Atmos. Chem., 33, 23-88, 1999.

Koppmann, R. and Wildt, J.: Oxygenated Volatile Organic Compounds, in: Volatile Organic Compounds in the Atmosphere, edited by: Koppmann, R., Blackwell Publishing Ltd, 4, 129-172, 2007.

Lindinger, W., Hansel, A., and Jordan, A.: On-line monitoring of volatile organic compounds at pptv levels by means of ProtonTransfer-Reaction Mass Spectrometry (PTR-MS). Medical applications, food control and environmental research, Int. J. Mass Spectrom. Ion Proc., 173, 191-241, 1998.

Loreto, F., Barta, C., Brilli, F., and Nogues, I.: On the induction of volatile organic compound emissions by plants as consequence of wounding or fluctuations of light and temperature, Plant Cell Environ., 29, 1820-1828, 2007.

Millet, D. B., Jacob, D. J., Custer, T. G., de Gouw, J. A., Goldstein, A. H., Karl, T., Singh, H. B., Sive, B. C., Talbott, R. W., Warneke, C., and Williams, J.: New constraints on terrestrial and oceanic sources of atmospheric methanol, Atmos. Chem. Phys. 8, 68876905, doi:10.5194/acp-8-6887-2008, 2008.

Millet, D. B., Atlas, E. L., Blake, D. R., Blake, N. J., Diskin, G. S., Holloway, J. S., Hudman, R. C., Meinardi, S., Ryerson, T. B., and Sachse, G. W.: Halocarbon Emissions from the United States and Mexico and Their Global Warming Potential, Environ. Sci. Technol., 43, 1055-1060, 2009.

Misztal, P. K., Owen, S. M., Guenther, A. B., Rasmussen, R., Geron, C., Harley, P., Phillips, G. J., Ryan, A., Edwards, D. P., Hewitt, C. N., Nemitz, E., Siong, J., Heal, M. R., and Cape, J. N.: Large estragole fluxes from oil palms in Borneo, Atmos. Chem. Phys. 10, 4343-4358, doi:10.5194/acp-10-4343-2010, 2010.

Noziere, B. and Riemer, D. D.: The chemical processing of gasphase carbonyl compounds by sulfuric acid aerosols- 2,4 pentanedione, Atmos. Environ., 37, 841-851, 2003.
Niinemets, Ü., Arneth, A., Kuhn, U., Monson, R. K., Peñuelas, J., and Staudt, M.: The emission factor of volatile isoprenoids: stress, acclimation, and developmental responses, Biogeosciences, 7, 2203-2223, doi:10.5194/bg-7-2203-2010, 2010.

Ormeño, E., Gentner, D. R., Fares, S., Karlik, J., Park, J. H., and Goldstein, A. H.: Sesquiterpenoid emissions from agricultural crops: correlations to monoterpenoid emissions and leaf terpene content Environ. Sci. Technol. 44, 3758-3764, 2010.

Ormeño, E., Goldstein, A., and Niinemets, U.: Extracting and trapping biogenic volatile organic compounds stored in plant species, Trends Analyt. Chem., 30, 978-989, 2011.

Papiez, M. R., Potosnak, M. J., Guenther, A. B., Matsunaga, S. N., and Stockwell, W. R.: The impacts of reactive terpene emissions from plants on air quality in Las Vegas, Nevada, Atmos. Environ., 43, 4109-4123, 2009.

Pare, P. W. and Tumlinson, J. H.: Plant volatiles as a defense against insect herbivores, Plant Physiol., 121, 325-331, 1999.

Rasulov, B., Huve K., Valbe, M., Laisk, A., and Niinemets, U.: Evidence That Light, Carbon Dioxide, and Oxygen Dependencies of Leaf Isoprene Emission Are Driven by Energy Status in Hybrid Aspen, Plant Physiol., 151, 448-460, 2009.

Riemer, D., Pos, W., Milne, P., Farmer, C., Zika, R., Apel, E., Olszyna, K,. Kliendienst, T., Lonneman, W., Bertman, S., Shepson, P., and Starn, T.: Observations of nonmethane hydrocarbons andoxygenated volatile organic compounds at a rural site in the southeastern United States, J. Geophys. Res., 103, 28111-28128, 1998.

Ruuskanen, T. M., Müller, M., Schnitzhofer, R., Karl, T., Graus, M., Bamberger, I., Hörtnagl, L., Brilli, F., Wohlfahrt, G., and Hansel, A.: Eddy covariance VOC emission and deposition fluxes above grassland using PTR-TOF, Atmos. Chem. Phys., 11, 611-625, doi:10.5194/acp-11-611-2011, 2011.

Schade, G. W. and Goldstein, A. H.: Plant physiological influences on the fluxes of oxygenated volatile organic compounds from ponderosa pine trees, J. Geophys. Res., 107, 4082, doi:10.1029/2001JD000532, 2002.

Seco, R., Peñuelas, J., and Filella, I.: Short-chain oxygenated VOCs: Emission and uptake by plants and atmospheric sources, sinks, and concentrations. Atmos. Environ., 41, 2477-2499, 2007.

Singh, H., Chen, Y., Staudt, A., Jacob, D., Blake, D., Heikes, B., and Snow, J.: Evidence from the Pacific troposphere for large global sources of oxygenated organic compounds, Nature, 410, 6832, 1078-1081, 2001.

Smith, A. M., Rigler, E., Kwok, E. S. C., and Atkinson, R.: Kinetics and products of the gas-phase reactions of 6-methyl-5-hepten-2one and trans-cinnamaldehyde with $\mathrm{OH}$ and $\mathrm{NO} 3$ radicals and O3. Environ. Sci. Technol., 30, 1781-1785, 1996.

Steiner, A. and Goldstein, A. H.: Biogenic volatile organic compounds, In Volatile Organic Compounds in the Atmosphere, edited by: Koppmann, R., Blackwell Publishing Ltd., 2007.

Tingey, D. T., Turner, D. P., and Weber, L. C.: Factors controlling the emission of monoterpenes and other volatile organic compounds, In Trace Gas Emissions by Plants, 65, edited by: Sharkey, T. D., Holland, E. A., and Mooney, H. A., 797-801, Academic Press, San Diego, California, USA, 1991.

van Schie, C. C. N., Haring, M. A., and Schuurink, R. C.: Regulation of terpenoid and benzenoid production in flowers, Curr. Op. Plant Biol., 9, 203-208, 2006. 
Wienhold, F. G., Frahm, H., and Harris, G. W.: Measurements of $\mathrm{N} 2 \mathrm{O}$ fluxes from fertilized grassland using a fast response tunable diode laser spectrometer, J. Geophys. Res., 99, 8 16557$16567,1994$.
Wilczak, J. M., Oncley, S. P., and Stage, S. A.: Sonic anemometer tilt correction algorithms, Bound.-Lay. Meteorol., 99, 127-150, 2001. 